\title{
A simple scoring system for predicting early major complications in spine surgery: the cumulative effect of age and size of surgery
}

\author{
Escore simples para predizer complicações precoces graves em cirurgia de coluna: \\ o efeito cumulativo da idade e tamanho da cirurgia \\ Albert Vincent Berthier Brasil', Alisson R. Teles², Marcelo Ricardo Roxo ${ }^{1}$, Marcelo Neutzling Schuster ${ }^{1}$, \\ Eduardo Ballverdu Zauk', Gabriel da Costa Barcellos', Pablo Ramon Fruett da Costa', Nelson Pires \\ Ferreira ${ }^{1}$, Jorge Luiz Kraemer ${ }^{1}$, Marcelo Paglioli Ferreira ${ }^{1}$, Pedro Luis Gobbato ${ }^{1}$, Paulo Valdeci Worm ${ }^{1}$
}

\begin{abstract}
Objective: To analyze the cumulative effect of risk factors associated with early major complications in postoperative spine surgery. Methods: Retrospective analysis of 583 surgically-treated patients. Early "major" complications were defined as those that may lead to permanent detrimental effects or require further significant intervention. A balanced risk score was built using multiple logistic regression. Results: Ninety-two early major complications occurred in 76 patients (13\%). Age $>60$ years and surgery of three or more levels proved to be significant independent risk factors in the multivariate analysis. The balanced scoring system was defined as: 0 points (no risk factor), 2 points ( 1 factor) or 4 points ( 2 factors). The incidence of early major complications in each category was $7 \%$ (0 points), $15 \%$ ( 2 points) and 29\% (4 points) respectively. Conclusions: This balanced scoring system, based on two risk factors, represents an important tool for both surgical indication and for patient counseling before surgery.
\end{abstract}

Keywords: spine, surgery; surgical wound invection; multivariate analysis.

\section{RESUMO}

Objetivo: Analisar os efeitos cumulativos dos fatores de risco associados com complicações precoces graves relacionadas à cirurgia da coluna. Métodos: Análise retrospectiva de 583 pacientes tratados cirurgicamente. Complicações graves foram definidas como as que pudessem levar a danos permanentes ou que necessitassem de reinterveção. Um escore foi construído usando modelo de regressão logística. Resultados: Noventa e duas complicações precoces graves ocorreram em 76 pacientes (13\%). Idade > 60 anos e cirurgia > 3 níveis foram identificadas como fatores de risco independentes na análise multivariada. 0 escore foi definido como: 0 pontos (nenhum fator de risco), 2 pontos (1 fator) ou 4 pontos (2 fatores). A incidência de complicação grave precoce em cada categoria foi 7\% (0 pontos), 15\% (2 pontos) e 29\% (4 pontos). Conclusões: Esse escore balanceado baseado em 2 fatores de risco representa uma ferramenta útil na indicação cirúrgica e para o aconselhamento dos pacientes antes da cirurgia.

Palavras-chave: coluna vertebral, cirurgia; infecção da ferida operatória; análise multivariada.

The decision whether or not to recommend a surgery for a patient must take into consideration the risks of complications ${ }^{1,2}$. In tertiary care spine surgery services, the incidence of complications may vary between $4 \%$ and $22 \%^{3,4,5}$. The risk of complications is usually presented in the literature as isolated functions of the patients' characteristics (e.g. age ${ }^{6}$ and obesity ${ }^{7}$, type of disease (e.g. lumbar stenosis ${ }^{8}$ and spondylolisthesis $\left.{ }^{9}\right)$ or type of surgery (e.g. anterior cervical discectomy and fusion ${ }^{10}$ and cervical arthroplasty ${ }^{11}$.)

Patient characteristics, type of disease and type of surgery vary independently, leaving the surgeon with serious difficulty informing about surgical risk. The clinical practice of spine surgery comprises a heterogeneous group of medical situations. Although an extensive amount of information about complications in spine surgery is available, few

${ }^{1}$ Hospital São José, Irmandade Santa Casa de Misericórdia de Porto Alegre, Departamento de Neurocirurgia, Porto Alegre RS, Brasil; ${ }^{2}$ Montreal Neurological Hospital and Institute, McGill University, Department of Neurology and Neurosurgery, Montreal QC, Canada.

Correspondence: Albert Vincent Berthier Brasil; Rua Germano Petersen Jr., 101 / Conj. 909; 90540-140 Porto Alegre RS, Brasil; E-mail: albertvb@terra.com.br Conflicts of interest: There is no conflict of interest to declare.

Support: ISCMPA receives financial support from Synthes Indústria e Comércio Ltda. for teaching material and guest speaker's expenses for an Educational Program in Spine Surgery.

Received 27 March 2016; Received in final form 10 June 2016; Accepted 20 June 2016 
studies address the cumulative effect of risk factors in a heterogeneous group of patients, diseases and surgeries. In other words, few studies focus on the issue of preoperative risk calculation in the way cases really present to surgeons ${ }^{4}$. No comprehensive instrument for the prediction of complications in spine surgery has been published so far ${ }^{1,3}$.

Our purpose is to analyze the cumulative effect of risk factors commonly associated with early major postoperative complications in a cohort of patients with heterogeneous medical characteristics, diseases and surgeries.

\section{METHODS}

This study is a retrospective analysis of prospectively collected data on a cohort of surgically-treated patients. Patients admitted to Hospital São José between 2012 and 2014 to receive open spine surgery under general anesthesia were included. A specially-designed registry system was initially tested in a subgroup of patients. After this, all patients were included.

There were 583 patients included in the study. After signing the informed consent, weight and height were measured and a questionnaire about comorbidities was completed. Immediately after the surgery another questionnaire was recorded with an extensive register of the clinical and radiographic preoperative data, as well as the details of the operative procedure. At the moment of discharge, a third questionnaire was completed describing immediate postoperative progression and the occurrence of complications. If the patient was readmitted for a complication, yet another questionnaire was completed at the moment of the second discharge, describing the complication and its management. Data collected prospectively contained information about different risk factors previously linked to postoperative complications in spine surgery.

Some terms utilized in this study were defined as follows:

1) The surgery was considered circumferential when two approaches (anterior and posterior) were used, or when dorsal and ventral surgery was performed using the posterolateral approach (e.g. thoracolumbar complete or partial vertebral body resections via posterolateral approach, pedicle subtraction osteotomies and interbody fusion associated to posterolateral instrumentation). All but two of the cases of anterior plus posterior approach were operated on, under a single anesthesia.

2) Surgeries were called "long" if they involved three or more levels.

3) One-level is considered to be one functional spinal unit (a pair of adjacent vertebrae with its corresponding discoligamentous complex). One-level surgery corresponds to the surgical manipulation of two adjacent vertebrae (e.g. lumbar microdiscectomy), and one-level instrumentation corresponds to the instrumentation of two adjacent vertebrae. Two-level arthrodesis corresponds to arthrodesis of three vertebrae, and so on. In the case of osteoplastic laminotomies or laminectomies for intradural pathology, the number of vertebrae involved was considered.

4) "Other diseases" included: intradural tumors and vascular malformations, Chiari/syringomyelia, primary osseous tumors, infections, thoracic disk, post-traumatic deformity, retro-odontoid pannus, spinal epidural hematoma and ossification of the yellow ligament.

5) Postoperative cerebrospinal fluid (CSF) leaks are a postoperative persistence of CSF flow through the dural suture (in incidental or elective durotomy) leading to a subcutaneous fluid collection with frank fluctuation or, sometimes, pouring of CSF through the skin suture line.

6) Seroma is the postoperative collection of bloodish subcutaneous fluid without signs of infection or CSF leaking, presenting with fluctuation of the skin and risk of suture opening, or even the spontaneous pouring of bloodish fluid through the suture line.

Complications were classified as "major" if they led to permanent detrimental effects or required further significant intervention ${ }^{3}$. Complications occurring during surgery or within the first 30 postoperative days were considered appropriate for the study.

For statistical purposes, the complications (categoric variables) were described by their absolute $(n)$ and relative (\%) frequencies and compared by the chi-square test for univariate analysis. In order to build a risk score (outcome = patient with one or more major intraoperative or 30-day major complication), the pathophysiological plausibility of potential risk factors found significant in univariate analysis were used. Logistic regression with the backward method was used and the final model maintained only the risk factors with a significance level $<0.05$ during the modeling steps. A balanced risk score was built based on the magnitude of factors in the logistic equation, using the odds ratio (OR) values rounded to the unit to determine the value of each risk factor. For the purpose of multivariate analysis, patients experiencing more than one major complication were considered as a single patient with major complications.

\section{RESULTS}

General characteristics of the cohort are presented in Table 1. Ninety-two early major complications occurred in 76 patients (13\%). Fifteen patients presented with more than one major complication. The types of complications are presented in Table 2. Wound complications (seromas, wound abscesses, CSF leaks, donor site infections and pseudomeningoceles) were the most common (50/76 patients, $65.78 \%$ ). Two cases of meningitis were associated with surgical site infection, so they were not added to the total number of infected patients. The total surgical infection rate was 33/583 (5.66\%). One 
Table 1. General characteristics of the cohort.

\begin{tabular}{lcc}
\hline Variable & $\mathrm{n}$ & $\%$ \\
\hline Patients & 583 & 100 \\
Age & $51 \pm 16$ & - \\
Male/female & $290 / 292$ & - \\
Body Mass Index & $27 \pm 4$ & - \\
1 Complication & 61 & 10.4 \\
2 Complications & 14 & 2.4 \\
3 Complications & 1 & 0.1 \\
Complications (total) & 76 & 13 \\
30-day mortality & 5 & 0.85 \\
Lumbar degenerative & 334 & 57 \\
Cervical degenerative & 78 & 13 \\
Trauma & 40 & 7 \\
Metastasis & 67 & 11 \\
Other diseases & 64 & 11 \\
Cervical & 115 & 20 \\
Cervicothoracic & 20 & 3 \\
Thoracic & 61 & 10 \\
Thoracolumbar & 35 & 6 \\
Lumbar & 315 & 54 \\
Lumbosacral & 27 & 5 \\
Sacral & 3 & 1 \\
Thoracolumbosacral & 3 & 1 \\
\hline
\end{tabular}

patient died of systemic inflammatory response syndrome 24 hours after a degenerative deformity surgery and this was considered a surgical mortality. Four patients (all with metastases and advanced cancer) died from medical problems not directly related to the surgery within the first 30 postoperative days, comprising a $0.85 \%$ global 30 -day mortality.

Table 3 shows the results of univariate analysis of all risk factors. The factors that were statistically significant for the occurrence of early major complications were: age $>60$ years $(\mathrm{OR}=2.59$, 95\%CI: 1.59-4.222, $\mathrm{p}<0.001)$, circumferential surgery $(\mathrm{OR}=1.91,95 \% \mathrm{CI}: 1.05-3.48, \mathrm{p}=0.027)$, long surgery $(\mathrm{OR}=2.87,95 \% \mathrm{CI}: 1.75-4.70, \mathrm{p}<0.001)$, metastatic disease $(\mathrm{OR}=1.93$, 95\%CI: $1.01-3.69, \mathrm{p}=0.013)$, and instrumentation $(\mathrm{OR}=1.76,95 \% \mathrm{CI}: 1.06-2.90, \mathrm{p}=0.025)$.

Significant risk factors identified in the univariate analysis were included in the multivariate analysis models (Table 4). Age above 60 years and long surgery proved to be significant independent risk factors for the occurrence of early major complications after multivariate analysis.

A risk score was built by ascribing a number of points to each one of the risk factors that had been demonstrated to be significant in the multivariate analysis. The number of points was determined by rounding to the OR to the unit. The two ORs achieved a value of 2 , showing that their power was similar. Three possible categories of risk were then built, according to the scores of each patient: no risk factor - 0 points, 2 and 4 points. The incidence of early major complications in each category was examined and is shown in Table $5-0$ points $=7 \%, 2$ points $=15 \%$ and 4 points $=29 \%$.
Table 2. Complications.

\begin{tabular}{|c|c|c|}
\hline Complication & $\mathrm{n}$ & $\begin{array}{l}\text { Positive } \\
\text { culture }\end{array}$ \\
\hline Seroma & 21 & 13 \\
\hline Abscess & 15 & 14 \\
\hline CSF Leak & 8 & 4 \\
\hline Dehiscense & 4 & - \\
\hline Iliac infection & 3 (1 isolated) & 1 (new) \\
\hline Pseudomeningocele & 1 & - \\
\hline Neurological deficit & 7 & - \\
\hline Malpositioned prosthesis & 6 & - \\
\hline Early death & 5 & - \\
\hline Respiratory insufficiency & 4 & - \\
\hline Meningitis & $\begin{array}{l}2 \text { (both with } \\
\text { abscess) }\end{array}$ & - \\
\hline Wrong site surgery & 2 & - \\
\hline Delirium & 2 & - \\
\hline Neuropathic pain & 2 & - \\
\hline Septic Shock & 2 & - \\
\hline $\begin{array}{l}\text { SIRS, pedicle fracture, } \\
\text { ischemic stroke, blindness, } \\
\text { acute myocardial infarction, } \\
\text { anesthetic complication, acute } \\
\text { kidney insufficiency, incomplete } \\
\text { decompression }\end{array}$ & 8 (1 of each) & - \\
\hline Total & 92 & $32(33)$ \\
\hline Patients with 2 complications & 14 & - \\
\hline Patients with 3 complications & 1 & - \\
\hline
\end{tabular}

\section{DISCUSSION}

The definition of complication in spine surgery is elusive $e^{4,12}$. The interchangeability of the terms "adverse event" and "complication" compounds this discussion ${ }^{13}$. The specific incidence of complications varies among different studies $^{14}$ and is higher when measured prospectively ${ }^{15}$. It seems that the measurement of major complications is more consistent among different studies, whereas the incidence of minor complications is more subject to methodological variations ${ }^{3,14}$. Fortunately, the consequences of minor complications appear to have little impact in the patients' longterm outcomes ${ }^{4}$. We chose to study major complications occurring during surgery or during the first month because they are more consistently defined, identified and registered. Besides that, patients are even more concerned than their surgeons about the risk of major complications when deciding whether to undergo the operation or not ${ }^{12}$.

Risk factors found to be significant in the present study have been widely discussed in the past ${ }^{14,16,17}$.

\section{Isolated risk factors (univariate analysis)}

Five risk factors proved significant for the occurrence of complications: age $\geq 60$ years, long surgery, circumferential surgery, instrumentation and metastatic disease.

Age, sometimes above $60^{18}$, sometimes above 65 or as a continuous variable $e^{6,7,19}$ is consistently associated with 
Table 3. Univariate analysis of risk factors.

\begin{tabular}{|c|c|c|c|c|c|}
\hline Variables & $\begin{array}{c}\text { Total Population } \\
(n=583)\end{array}$ & $\begin{array}{c}\text { Group without early and } \\
\text { major complications } \\
(n=507)\end{array}$ & $\begin{array}{l}\text { Group with early and } \\
\text { major complications } \\
(n=76)\end{array}$ & $\begin{array}{c}\mathrm{RR} \\
(95 \% \mathrm{Cl})\end{array}$ & $\mathrm{p}$ \\
\hline \multicolumn{6}{|l|}{ Gender } \\
\hline $\begin{array}{l}\text { Women } \\
\text { Men }\end{array}$ & $\begin{array}{l}292(50 \%) \\
290(50 \%)\end{array}$ & $\begin{array}{l}256(88 \%) \\
250(86 \%)\end{array}$ & $\begin{array}{l}36(12 \%) \\
40(14 \%)\end{array}$ & $\begin{array}{c}1.14 \\
(0.70-1.84)\end{array}$ & 0.600 \\
\hline \multicolumn{6}{|l|}{ Age } \\
\hline $\begin{array}{l}>60 \text { years } \\
<60 \text { years }\end{array}$ & $\begin{array}{l}192(33 \%) \\
390(67 \%)\end{array}$ & $\begin{array}{l}152(79 \%) \\
354(91 \%)\end{array}$ & $\begin{array}{c}40(21 \%) \\
36(9 \%)\end{array}$ & $\begin{array}{c}2.59 \\
(1.59-4.22)\end{array}$ & $<0.001$ \\
\hline \multicolumn{6}{|l|}{ Obesity (BMI > 30) } \\
\hline $\begin{array}{l}\text { Yes } \\
\text { No }\end{array}$ & $\begin{array}{l}124(25 \%) \\
439(75 \%)\end{array}$ & $\begin{array}{l}104(84 \%) \\
384(87 \%)\end{array}$ & $\begin{array}{l}20(16 \%) \\
55(13 \%)\end{array}$ & $\begin{array}{c}1.34 \\
(0.77-2.34)\end{array}$ & 0.297 \\
\hline \multicolumn{6}{|l|}{ Obesity (BMI > 35) } \\
\hline $\begin{array}{l}\text { Yes } \\
\text { No }\end{array}$ & $\begin{array}{c}31(5 \%) \\
532(95 \%)\end{array}$ & $\begin{array}{c}24(77 \%) \\
464(87 \%)\end{array}$ & $\begin{array}{l}7(23 \%) \\
68(13 \%)\end{array}$ & $\begin{array}{c}1.99 \\
(0.83-4.80)\end{array}$ & 0.119 \\
\hline \multicolumn{6}{|c|}{ Lumbar degenerative disease } \\
\hline $\begin{array}{l}\text { Yes } \\
\text { No }\end{array}$ & $\begin{array}{l}334(57 \%) \\
249(43 \%)\end{array}$ & $\begin{array}{l}297(89 \%) \\
210(84 \%)\end{array}$ & $\begin{array}{l}37(11 \%) \\
39(16 \%)\end{array}$ & $\begin{array}{c}0.67 \\
(0.41-1.09)\end{array}$ & 0.104 \\
\hline \multicolumn{6}{|l|}{ Trauma } \\
\hline $\begin{array}{l}\text { Yes } \\
\text { No }\end{array}$ & $\begin{array}{c}40(7 \%) \\
543(93 \%)\end{array}$ & $\begin{array}{l}33(83 \%) \\
474(87 \%)\end{array}$ & $\begin{array}{l}7(17 \%) \\
69(13 \%)\end{array}$ & $\begin{array}{c}1.46 \\
(0.62-3.42)\end{array}$ & 0.385 \\
\hline \multicolumn{6}{|c|}{ Cervical degenerative disease } \\
\hline $\begin{array}{l}\text { Yes } \\
\text { No }\end{array}$ & $\begin{array}{l}78(13 \%) \\
505(87 \%)\end{array}$ & $\begin{array}{l}70(90 \%) \\
437(87 \%)\end{array}$ & $\begin{array}{l}8(10 \%) \\
68(13 \%)\end{array}$ & $\begin{array}{c}0.73 \\
(0.34-1.59)\end{array}$ & 0.433 \\
\hline \multicolumn{6}{|l|}{ Metastasis } \\
\hline $\begin{array}{l}\text { Yes } \\
\text { No }\end{array}$ & $\begin{array}{c}67(11 \%) \\
516(89 \%)\end{array}$ & $\begin{array}{l}53(79 \%) \\
454(88 \%)\end{array}$ & $\begin{array}{l}14(21 \%) \\
62(12 \%)\end{array}$ & $\begin{array}{c}1.93 \\
(1.01-3.69)\end{array}$ & 0.042 \\
\hline \multicolumn{6}{|l|}{ Other diseases } \\
\hline $\begin{array}{l}\text { Yes } \\
\text { No }\end{array}$ & $\begin{array}{c}64(11 \%) \\
519(89 \%)\end{array}$ & $\begin{array}{l}54(84 \%) \\
453(87 \%)\end{array}$ & $\begin{array}{l}10(16 \%) \\
66(13 \%)\end{array}$ & $\begin{array}{c}1.27 \\
(0.62-2.62)\end{array}$ & 0.514 \\
\hline \multicolumn{6}{|l|}{ Approach } \\
\hline $\begin{array}{l}\text { Circumferential } \\
\text { Single }\end{array}$ & $\begin{array}{l}84(15 \%) \\
495(85 \%)\end{array}$ & $\begin{array}{l}67(80 \%) \\
437(88 \%)\end{array}$ & $\begin{array}{l}17(20 \%) \\
58(12 \%)\end{array}$ & $\begin{array}{c}1.91 \\
(1.05-3.48)\end{array}$ & 0.032 \\
\hline \multicolumn{6}{|c|}{ Extension of procedure } \\
\hline $\begin{array}{l}\text { Long (3 or more) } \\
\text { Short (2 or less) }\end{array}$ & $\begin{array}{l}190(33 \%) \\
389(67 \%)\end{array}$ & $\begin{array}{l}149(78 \%) \\
355(91 \%)\end{array}$ & $\begin{array}{l}41(22 \%) \\
34(9 \%)\end{array}$ & $\begin{array}{c}2.87 \\
(1.75-4.70)\end{array}$ & $<0.001$ \\
\hline \multicolumn{6}{|l|}{ Instrumentation } \\
\hline $\begin{array}{l}\text { Yes } \\
\text { No }\end{array}$ & $\begin{array}{l}279(52 \%) \\
277(48 \%)\end{array}$ & $\begin{array}{l}233(84 \%) \\
249(90 \%)\end{array}$ & $\begin{array}{l}46(16 \%) \\
28(10 \%)\end{array}$ & $\begin{array}{c}1.76 \\
(1.06-2.90)\end{array}$ & 0.027 \\
\hline Motor deficit & & & & & \\
\hline $\begin{array}{l}\text { Yes } \\
\text { No }\end{array}$ & $\begin{array}{l}70(15 \%) \\
495(85 \%)\end{array}$ & $\begin{array}{l}57(81 \%) \\
435(88 \%)\end{array}$ & $\begin{array}{l}13(19 \%) \\
60(12 \%)\end{array}$ & $\begin{array}{c}1.64 \\
(0.85-3.20)\end{array}$ & 0.132 \\
\hline Cholesterol & & & & & \\
\hline $\begin{array}{l}\text { Yes } \\
\text { No }\end{array}$ & $\begin{array}{c}7(1 \%) \\
576(99 \%)\end{array}$ & $\begin{array}{c}5(71 \%) \\
502(87 \%)\end{array}$ & $\begin{array}{c}2(29 \%) \\
74(13 \%)\end{array}$ & $\begin{array}{c}2.71 \\
(0.52-14.24)\end{array}$ & 0.219 \\
\hline Smoking & & & & & \\
\hline $\begin{array}{l}\text { Yes } \\
\text { No }\end{array}$ & $\begin{array}{l}77(13 \%) \\
506(87 \%)\end{array}$ & $\begin{array}{l}71(92 \%) \\
436(86 \%)\end{array}$ & $\begin{array}{c}6(8 \%) \\
70(14 \%)\end{array}$ & $\begin{array}{c}0.53 \\
(0.22-1.26)\end{array}$ & 0.142 \\
\hline Hypertension & & & & & \\
\hline $\begin{array}{l}\text { Yes } \\
\text { No }\end{array}$ & $\begin{array}{l}193(33 \%) \\
389(67 \%)\end{array}$ & $\begin{array}{l}162(84 \%) \\
345(89 \%)\end{array}$ & $\begin{array}{l}31(16 \%) \\
44(11 \%)\end{array}$ & $\begin{array}{c}1.50 \\
(0.91-2.46)\end{array}$ & 0.107 \\
\hline Diabetes Mellitus & & & & & \\
\hline $\begin{array}{l}\text { Yes } \\
\text { No }\end{array}$ & $\begin{array}{l}57(10 \%) \\
524(90 \%)\end{array}$ & $\begin{array}{l}48(84 \%) \\
458(87 \%)\end{array}$ & $\begin{array}{l}9(16 \%) \\
66(13 \%)\end{array}$ & $\begin{array}{c}1.30 \\
(0.61-2.77)\end{array}$ & 0.495 \\
\hline Gastrointestinal d & & & & & \\
\hline $\begin{array}{l}\text { Yes } \\
\text { No }\end{array}$ & $\begin{array}{c}23(4 \%) \\
560(96 \%)\end{array}$ & $\begin{array}{l}19(83 \%) \\
488(87 \%)\end{array}$ & $\begin{array}{c}4(17 \%) \\
72(13 \%)\end{array}$ & $\begin{array}{c}1.43 \\
(0.47-4.31)\end{array}$ & 0.527 \\
\hline Alcohol & & & & & \\
\hline $\begin{array}{l}\text { Yes } \\
\text { No }\end{array}$ & $\begin{array}{c}6(1 \%) \\
577(99 \%)\end{array}$ & $\begin{array}{c}5(83 \%) \\
502(87 \%)\end{array}$ & $\begin{array}{c}1(17 \%) \\
75(13 \%)\end{array}$ & $\begin{array}{c}1.34 \\
(0.15-11.62)\end{array}$ & 0.791 \\
\hline Drugs & & & & & \\
\hline $\begin{array}{l}\text { Yes } \\
\text { No }\end{array}$ & $\begin{array}{c}2(1 \%) \\
581(99 \%)\end{array}$ & $\begin{array}{c}2(100 \%) \\
505(87 \%)\end{array}$ & $\begin{array}{c}0(0 \%) \\
76(13 \%)\end{array}$ & $\begin{array}{c}0.87 \\
(0.84-0.90)\end{array}$ & 0.583 \\
\hline Anxiety & & & & & \\
\hline $\begin{array}{l}\text { Yes } \\
\text { No }\end{array}$ & $\begin{array}{l}131(22 \%) \\
452(78 \%)\end{array}$ & $\begin{array}{l}112(85 \%) \\
395(87 \%)\end{array}$ & $\begin{array}{l}19(15 \%) \\
57(13 \%)\end{array}$ & $\begin{array}{c}1.18 \\
(0.67-2.06)\end{array}$ & 0.571 \\
\hline Depression & & & & & \\
\hline $\begin{array}{l}\text { Yes } \\
\text { No }\end{array}$ & $\begin{array}{l}89(15 \%) \\
494(85 \%)\end{array}$ & $\begin{array}{l}74(83 \%) \\
433(88 \%)\end{array}$ & $\begin{array}{l}15(17 \%) \\
61(12 \%)\end{array}$ & $\begin{array}{c}1.44 \\
(0.77-2.66) \\
\end{array}$ & 0.245 \\
\hline
\end{tabular}


Table 4. Logistic regression and multivariable risk score ( modeling $n=556$ ).

\begin{tabular}{lccccc}
\hline Variables & B coefficient & OR & $95 \% \mathrm{Cl}$ & $\mathrm{p}$ & points \\
\hline Age $>60 \mathrm{y}$ & 0.87 & 2.38 & $1.43-3.95$ & 0.001 & 2 \\
Surgery $>3$ levels & 0.91 & 2.49 & $1.50-4.14$ & $<0.001$ & 2 \\
\hline OR: Odds ratio. & & & &
\end{tabular}

Table 5. Risk and complications according to three risk categories ( $n=578)$.

\begin{tabular}{lccc}
\hline Score & $\begin{array}{c}\text { Population } \\
(n=578)\end{array}$ & $\begin{array}{ccc}\text { Complications } n(\%) \\
(n=76)\end{array}$ & Risk categories \\
\hline 0 & 282 & $19(7 \%)$ & Low \\
2 & 211 & $31(15 \%)$ & Medium \\
4 & 85 & $25(29 \%)$ & High \\
\hline
\end{tabular}

complications. This is probably due to the fact that the incidence of comorbidities increases with age ${ }^{6}$. The relation of surgical complications with isolated or combined comorbidities has been well demonstrated ${ }^{14}$. In the present study, many comorbidities were evaluated but none of them was, by itself, significant. It seems that age presents with an increased number of "sick patients" even when the isolated impact of each comorbidity cannot be detected.

A surgery performed over three or more levels was the most significant isolated risk factor for the occurrence of complications. Other authors have previously demonstrated that surgeries over more levels are prone to an increased complication rate ${ }^{20}$. Increases in tissue disruption, operative time and bleeding are the most probable reasons for this widely-accepted concept.

Circumferential surgeries represent a more complex procedure. Analyses of large cohorts usually show that these cases are accompanied by more complications ${ }^{21}$ than those involving only posterior or anterior manipulation. In our material, $360^{\circ}$ arthrodesis with interbody cages was also considered circumferential surgery because it also involves the "three columns", takes a longer time and bleeds more. Although the placement of an interbody cage obviously transforms a posterolateral fusion into a larger surgery, some series show an increased complication rate ${ }^{22}$ while others do not ${ }^{9}$. In our material, the risk of complications was almost twice that of a circumferential surgery.

Instrumentation adds time and bleeding to the procedure. If one also considers the presence of metals and bone grafts, a higher grade of "invasiveness" becomes apparent. The isolated risk offered by instrumentation has been documented ${ }^{23,24}$. In our material this increased risk was also well demonstrated.

Patients harboring spinal metastases are considered "sicker" than other patients undergoing spine surgery ${ }^{25}$. Consumption by the disease and/or the oncologic treatment promotes weight loss and immunological deficiency, which can correlate with an increased risk of perioperative complications $^{26}$. In our material, patients with metastatic disease had an almost twofold increase in complications when compared with the rest of the cohort.

\section{Elimination of confounding risk factors (multivariate analysis)}

An ideal system to predict complications should take into consideration risk factors related to the patient, to the surgery and to disease ${ }^{27}$. The present study analyzed factors from these three domains. In univariate analysis, the factors from the three domains demonstrated to be significant were: age (patient), long surgery, circumferential surgery and instrumentation (surgery) and metastatic disease (disease). After multivariate analysis, circumferential surgery, instrumentation and metastatic disease were eliminated.

The idea behind surgical risk scores is invariably bound to the concept of "invasiveness" of the surgery on the one hand, and to the patient's capacity to tolerate surgical stress on the other ${ }^{28}$.

In the special setting of spine surgery, the Spine Surgical Invasiveness Index was proposed as an instrument to make this prediction ${ }^{27}$. In this index, a precise description of exactly what is performed in each vertebra is registered. The index scores six types of intervention that can occur at each spinal level. The sum of all interventions in all vertebrae is a quantitative indicator of invasiveness of the procedure.

Few authors have addressed the cumulative effect of risk factors on the incidence of complications ${ }^{1,2,14,17}$. A recent study calculated surgical risk based on the patient's comorbidity profile, pattern of spine degeneration and Spine Surgical Invasiveness Index ${ }^{1}$. In this publication, the authors list a website that presents a large number of patient comorbidities, pattern of degeneration and characteristics of surgery in order to obtain a precise prediction of medical postoperative complications. The enormous effort of these authors is an ongoing process, which aims to build a comprehensive tool for predicting the occurrence of adverse events. In this case, the cost of precision is complexity. The relative complexity of the process of accessing a website and answering a questionnaire may represent a drawback to this proposition.

Multivariate analysis of our material confirms the reliability of age and length of surgery and eliminates instrumentation, circumferential surgery and metastatic disease. It is likely that in a larger cohort, the real weight of the last three factors may be demonstrated and quantified. On the other hand, one can argue that an age of 60 years or older is a common denominator of "sicker" patients and represents a simple and reliable indicator of reduced ability to tolerate the impact of surgery. At the same time, the number of levels operated upon may 
be a more rudimentary, but simpler, indicator of invasiveness. Perhaps the number of levels better describes the amount of tissue disruption. Perhaps tissue disruption is a stronger predictor of complications than the added time and bleeding observed in instrumented or circumferential surgeries. The perception that surgery for metastatic disease has an increased rate of complications might not be due to the presence of cancer in itself, but to the fact that these surgeries are usually long and performed mostly in elderly patients.

\section{Balanced scoring system}

The balanced scoring system demonstrates that a short surgery on a young patient carries a $7 \%$ risk of major complications. In the presence of an age of 60 years or older, or in cases of three or more levels, this risk doubles to $15 \%$. When both these risk factors are present, the incidence rises to $29 \%$.

In order to ascertain the reliability of our results, the baseline of $7 \%$ complication rate in short surgeries for young patients (which was observed in our material) must be compared to other series. A good example is offered by disk herniation, which generally fits into this description (one level, mostly young patients). In a 2011 review of the incidence of complications in 7,964 disk herniation surgeries performed by the Japanese Society for Spine Surgery and Related Research board certified surgeons, the incidence of complications was $5,6 \%{ }^{21}$, which compares fairly well to our cohort.

The balanced risk score (Table 5) shows results that specify and quantify the intuitive perception of spine surgeons: small surgeries in young patients are accompanied by fewer major complications (7\%) than large surgeries performed in older patients (29\%). Between these two extremes lie the cases with only one risk factor $(15 \%)$.
Using a very sophisticated method, Lee et al. ${ }^{29}$ reached conclusions quite similar to ours, but these were confined to medical complications. It seems unfair to compare the advantages of the more precise Spine Surgical Invasiveness Index ${ }^{1}$ with our simple scoring system because of the obvious superiority of the first. On the other hand, one can argue that in everyday bedside practice and office discussions, the simple allocation of cases in three classes of risk also has its advantages.

The inherent merits and drawbacks of simplicity and complexity will continue to fuel an eternal debate about value. Simplicity is the main quality of the score presented here, as well as its main drawback. Based on this very simple scoring system, patients can be reasonably informed about their surgical risk and bedside discussions can be better oriented, taking into consideration only the patient's age and the surgical plan. Another limitation of our study is that it reflects the reality of one center. It is recognized that the rate of surgical complications may be different among different centers performing the same procedures. We hope this score is validated in other centers in near future.

In conclusion, a balanced scoring system based on two risk factors for early major complications in spinal surgery was built. Based on OR, a number of points was attributed to age $>60$ years ( 2 points) and long surgery ( 2 points). The risk of early major complications for patients varied according to the sum of their points: $0=7 \%, 2=15 \%$ and $4=29 \%$.

Although further prospective studies employing the proposed simple scoring system are still necessary to validate its use in clinical practice, the incorporation of such simple and practical scores into the decision-making process of spine surgery practice constitutes an important tool for patient counseling before surgical treatment.

\section{References}

1. Lee MJ, Cizik AM, Hamilton D, Chapman JR. Predicting medical complications after spine surgery: a validated model using a prospective surgical registry. Spine J. 2014;14(2):291-9. doi:10.1016/j.spinee.2013.10.043

2. Mirza SK, Martin BI, Goodkin R, Hart RA, Anderson PA. Developing a toolkit for comparing safety in spine surgery. Instr Course Lect. 2014;63:271-86.

3. Campbell PG, Malone J, Yadla S, Chitale R, Nasser R, Maltenfort MG et al. Comparison of ICD-9-based, retrospective, and prospective assessments of perioperative complications: assessment of accuracy in reporting. J Neurosurg Spine. 2011;14(1):16-22. doi:10.3171/2010.9.SPINE10151

4. Dekutoski MB, Norvell DC, Dettori JR, Fehlings MG, Chapman JR et al. Surgeon perceptions and reported complications in spine surgery. Spine. 2010;35(9 Suppl):S9-21. doi:10.1097/BRS.0b013e3181d830 de

5. Deyo RA, Cherkin DC, Loeser JD, Bigos SJ, Ciol MA. Morbidity and mortality in association with operations on the lumbar spine: the influence of age, diagnosis, and procedure. J Bone Joint Surg Am. 1992;74(4):536-43.

6. Acosta FL, Jr., McClendon J Jr., O'Shaughnessy BA, Koller H, Neal CJ, Meier $\mathrm{O}$ et al. Morbidity and mortality after spinal deformity surgery in patients 75 years and older: complications and predictive factors. J Neurosurg Spine. 2011;15(6):667-74. doi:10.3171/2011.7.SPINE10640
7. Patel N, Bagan B, Vadera S, Maltenfort MG, Deutsch H, Vaccaro AR et al. Obesity and spine surgery: relation to perioperative complications.J Neurosurg Spine. 2007;6(4):291-7. doi:10.3171/spi.2007.6.4.1

8. Fu KM, Smith JS, Polly DW Jr, Perra JH, Sansur CA, Berven SH et al. Morbidity and mortality in the surgical treatment of 10,329 adults with degenerative lumbar stenosis. J Neurosurg Spine. 2010;12(5):443-6. doi:10.3171/2009.11.SPINE09531

9. Sansur CA, Reames DL, Smith JS, Hamilton DK, Berven SH, Broadstone PA et al. Morbidity and mortality in the surgical treatment of 10,242 adults with spondylolisthesis. J Neurosurg Spine. 2010;13(5):589-93. doi:10.3171/2010.5.SPINE09529

10. Fountas KN, Kapsalaki EZ, Nikolakakos LG, Smisson HF, Johnston KW, Grigorian AA et al. Anterior cervical discectomy and fusion associated complications. Spine. 2007;32(21):2310-7. doi:10.1097/BRS.0b013e318154c57e

11. Salari B, McAfee PC. Cervical total disk replacement: complications and avoidance. Orthop Clin North Am. 2012;43(1):97-107. doi:10.1016/j.ocl.2011.08.006

12. Ratliff JK, Lebude B, Albert T, Anene-Maidoh T, Anderson G, Dagostino $P$ et al. Complications in spinal surgery: comparative survey of spine surgeons and patients who underwent spinal surgery. J Neurosurg Spine. 2009;10(6):578-84. doi:10.3171/2009.2.SPINE0935 
13. Street JT, Lenehan BJ, DiPaola CP, Boyd MD, Kwon BK, Paquette SJ et al. Morbidity and mortality of major adult spinal surgery: a prospective cohort analysis of 942 consecutive patients. Spine J. 2012;12(1):22-34. doi:10.1016/j.spinee.2011.12.003

14. Campbell PG, Yadla S, Nasser R, Malone J, Maltenfort MG, RatliffJK. Patient comorbidity score predicting the incidence of perioperative complications: assessing the impact of comorbidities on complications in spine surgery. J Neurosurg Spine. 2012;16(1):37-43. doi:10.3171/2011.9.SPINE11283

15. Nasser R, Yadla S, Maltenfort MG, Harrop JS, Anderson DG, Vaccaro AR et al. Complications in spine surgery.J Neurosurg Spine. 2010;13(2):144-57. doi:10.3171/2010.3.SPINE09369

16. Ma Y, Passias P, Gaber-Baylis LK, Girardi FP, Memtsoudis SG Comparative in-hospital morbidity and mortality after revision versus primary thoracic and lumbar spine fusion. Spine J. 2010;10(10):881-9. doi:10.1016/j.spinee.2010.07.391

17. Charlson ME, Pompei P, Ales KL, Mackenzie CR. A new method of classifying prognostic comorbidity in longitudinal studies: development and validation. J Chronic Dis. 1987;40(5):373-83. doi:10.1016/0021-9681(87)90171-8

18. Fu KM, Smith JS, Sansur CA, Shaffrey Cl. Standardized measures of health status and disability and the decision to pursue operative treatment in elderly patients with degenerative scoliosis. Neurosurgery. 2010;66(1):42-7. doi:10.1227/01.NEU.0000361999.29279.E6

19. Benz RJ, Ibrahim ZG, Afshar P, Garfin SR. Predicting complications in elderly patients undergoing lumbar decompression. Clin Orthop Relat Res. 2001;384:116-21. doi:10.1097/00003086-200103000-00014

20. Shamji MF, Cook C, Pietrobon R, Tackett S, Brown C, Isaacs RE. Impact of surgical approach on complications and resource utilization of cervical spine fusion: a nationwide perspective to the surgical treatment of diffuse cervical spondylosis. Spine J. 2009;9(1):31-8. doi:10.1016/j.spinee.2008.07.005

21. Imajo Y, Taguchi T, Yone K, Okawa A, Otani K, Ogata T et al. Japanese 2011 nationwide survey on complications from spine surgery. J Orthop Sci. 2015;20(1):38-54. doi:10.1007/s00776-014-0656-6
22. Fritzell P, Hagg O, Wessberg P, Nordwall A. Chronic low back pain and fusion: a comparison of three surgical techniques: a prospective multicenter randomized study from the Swedish lumbar spine study group. Spine. 2002;27(11):1131-41. doi:10.1097/00007632-200206010-00002

23. Wang MC, Chan L, Maiman DJ, Kreuter W, Deyo RA. Complications and mortality associated with cervical spine surgery for degenerative disease in the United States. Spine. 2007;32(3):342-7. doi:10.1097/01.brs.0000254120.25411.ae

24. Deyo RA, Ciol MA, Cherkin DC, Loeser JD, Bigos SJ. Lumbar spinal fusion. A cohort study of complications, reoperations, and resource use in the Medicare population. Spine. 1993;18(11):1463-70. doi:10.1097/00007632-199318110-00010

25. Wang JC, Boland P, Mitra N, Yamada Y, Lis E, Stubblefield M et al. Single-stage posterolateral transpedicular approach for resection of epidural metastatic spine tumors involving the vertebral body with circumferential reconstruction: results in 140 patients. Invited submission from the Joint Section Meeting on Disorders of the Spine and Peripheral Nerves, March 2004. J Neurosurg Spine. 2004;1(3):287-98. doi:10.3171/spi.2004.1.3.0287

26. Cheng ML, Jaikumar S. Metastatic evaluation. In: Kim DH Chang UK, Kim SH, Bilsky MH, editors. Tumors of the spine. Philadelphia: Saunders Elsevier; 2008. p. 298-316.

27. Mirza SK, Deyo RA, Heagerty PJ, Turner JA, Lee LA, Goodkin R. Towards standardized measurement of adverse events in spine surgery: conceptual model and pilot evaluation. BMC Musculoskelet Disord. 2006;7(1):53. doi:10.1186/1471-2474-7-53

28. Jones HJ, Cossart L. Risk scoring in surgical patients. Br J Surg. 1999;86(2):149-57. doi:10.1046/j.1365-2168.1999.01006.x

29. Lee MJ, Konodi MA, Cizik AM, Bransford RJ, Bellabarba C, Chapman JR. Risk factors for medical complications after spine surgery: a multivariate analysis of 1.591 patients. Spine J. 2012;12(3):197-206. doi:10.1016/j.spinee.2011.11.008 